\title{
Limb-Girdle Muscular Dystrophy Type 2D
}

National Cancer Institute

\section{Source}

National Cancer Institute. Limb-Girdle Muscular Dystrophy Type 2D. NCI Thesaurus.

Code C142081.

An autosomal recessive condition caused by mutation(s) in the SGCA gene, encoding alpha-sarcoglycan. It is characterized by progressive muscular dystrophy, primarily affecting the proximal muscles, resulting in difficulty walking. 